\title{
Progress and Catastrophe: Public History at the Iowa State Fair, 1854-1946
}

\section{CHRIS RASMUSSEN}

The progress of Iowa might almost be recorded by a history of state fairs. The altering exhibits from year to year, the slow but steady introduction of new features, the growth of the experimental novelty of one year into a staple of a few years later, are a record of the development of the state and its people. ${ }^{1}$

THE YEAR 2004 marked the Iowa State Fair's 150th anniversary, a milestone in Iowa's history. The annual fair remains among the most significant and eagerly anticipated events on many Iowans' calendars, and the fairground in Des Moines might justifiably be regarded as the epicenter of Iowa's culture and identity. For a century and a half, the fair has offered Iowans an annual display of their society's development not only over the past year but since white settlement began in the 1830s. Passing through the fair's gates, visitors have always marveled at the exhibition, which showcases innovation and new technologies while at the same time hearkens back to the state's founding and its history. Over its history, however, the fair has become less devoted to change and more deeply rooted in tradition and continuity. While the fair still looks to the future and fosters progress, its basic elements remain remarkably unchanged after a century and a half of almost unimaginable economic and social transformation from the 1850 s to the first decade of the twenty-first century. The fair has now become a familiar, re-

1. Dante M. Pierce, "The State Fair and Its Record of Progress," Iowa Homestead 69 (1924), 1218.

THE ANNALS OF IOWA 63 (Fall 2004). (C) The State Historical Society of Iowa, 2004. 
assuring annual ritual, a touchstone of stability amid a world of ever-quickening change. ${ }^{2}$

From the first fair in 1854, the Iowa State Fair has consistently offered a hybrid of agricultural exhibits and entertainments, simultaneously promoting economic growth and providing fairgoers an annual carnival. Because Iowans widely considered the fair a microcosm of their society, they often debated the role of agriculture and entertainment at the fair. Agricultural exhibits have always supplied the fair's central purpose and saluted rural life and Iowa's productivity. Entertainments, on the other hand, provided the fair's allure, but embodied the values of an urbanized, leisure-oriented society. Because Iowa's economy and society were predicated on agriculture, some Iowans fretted that any departure from the fair's agricultural mission suggested that their society was neglecting the very basis of its prosperity. When they debated the respective place of agriculture (or education) and entertainment on the fairground, they were not only urging higher premiums for livestock exhibitors or grumping about a tawdry sideshow but also commenting on the past, present, and future of their state.

The annual state fair, one of Iowa's most important institutions, was widely regarded as a barometer of the state's economic and cultural achievements. The fair not only helped to foster the state's development, but also annually took the measure of Iowa's progress, tallying the steady growth of the state's population, economy, and agricultural bounty. In addition to its agricultural exhibits and entertainments, the Iowa State Fair joined Iowans together ritually by offering them a reassuring version of their history in which hardy pioneers subdued the frontier and laid the foundation for subsequent agricultural, industrial, and cultural advancement.

Over the past two decades, historians have become sensitive to the many ways in which history is conveyed to the public, most of which take place outside of the classroom. Today,

2. For histories of the fair, see the commemorative issue of the Palimpsest published to mark the fair's centenary in 1954. Palimpsest 35 (July 1954). See also Mary Kay Shanley, Our State Fair: Iowa's Blue Ribbon Story (Des Moines, 2000); and Chris Rasmussen, "State Fair: Culture and Agriculture in Iowa, 18541941" (Ph.D. diss., Rutgers University, 1992). 
Americans receive many of their history lessons from historic sites, museums, movies, and television programs, rather than from high school and college courses. ${ }^{3}$ Over time, the state fair offered Iowans instruction in history through its historical exhibits, by tallying Iowa's progress since the pioneer era, and even through its grandstand spectacles.

From its inception in 1854 to its centennial exhibition in 1946, the state fair told Iowa's history in many ways. For the most part, the fair offered a story of steady progress. Its exhibits reaffirmed Iowans' shared heritage by reminding them of their debt to the hardy pioneers who first crossed into Iowa Territory and broke the prairie and of their shared history of steady and ongoing progress since then. Nearly all of the fair's displays were designed to measure and celebrate Iowans' attainments in agriculture, home-making, manufacturing, crafts, and fine arts: bigger cattle, larger yields, nicer homes, more efficient machinery, more beautiful paintings. Often, the fair also included specifically historical exhibits that chronicled the steady advances Iowans had made since the frontier era.

The fair's most popular commercial entertainments between 1900 and 1930, on the other hand, recounted a much less optimistic history lesson. For decades, the fair's biggest draw was a nightly disaster spectacle, which depicted destruction on a vast scale, as the result of either natural disaster or war. These spectacles re-enacted sudden, wanton destruction that brought progress and civilization crashing to a halt. Instead of gradual, inevitable progress, these spectacles suggested a history punctuated by catastrophe and sudden decline. The fair's exhibits and its entertainments, always in some tension with one another, suggested nearly antithetical views of history and of the certainty of progress. While the fair's exhibits represented steady progress, its most popular grandstand entertainments in the early twentieth century brooded over the threat of precipitous decline.

3. See esp. Roy Rosenzweig and David Thelen, The Presence of the Past: Popular Uses of History in American Life (New York, 1998). On the uses of ritual, see Paul Connerton, How Societies Remember (Cambridge, 1989), esp. 57-71. See also David Lowenthal, The Past is a Foreign Country (Cambridge, 1985); David Glassberg, American Historical Pageantry: The Uses of Tradition in the Early Twentieth Century (Chapel Hill, NC, 1990); and Michael Kammen, Mystic Chords of Memory: The Transformation of Tradition in American Culture (New York, 1992). 
During the Great Depression of the 1930s, the fair board revived the fair's longstanding theme, insisting that agriculture lay at the heart of the state's culture and that a renewed emphasis on agriculture would restore prosperity. Amid the economic wreck of the Great Depression, the fair sought to reassure Iowans that progress and prosperity, although temporarily in check, would certainly return. In the decades after World War II, the fair became less devoted to charting economic progress and inclined instead toward nostalgia. The history of the Iowa State Fair, then, recounts a long-running conversation about vast cultural and economic changes, about tensions between rural and urban America, about agricultural production and commercial entertainment, and about the ties that linked past, present, and future. In this sense it can truly be said that the history of the fair also records a significant portion of the history of the state.

IN 1833, the Territory of Iowa was opened to settlers, who quickly began peopling the eastern portion of the land. Settlers began holding county fairs in the early 1840s, and in 1853 the state legislature chartered the Iowa State Agricultural Society, an organization charged with improving the state's agricultural economy, compiling statistics on agriculture, and, most important, holding an annual state fair. In 1854 the first Iowa State Fair was held, appropriately, in Fairfield in southeast Iowa. Some ten thousand people, by far the largest crowd ever assembled in the frontier state, congregated on and around the six-acre fairground. Lawyer George C. Dixon of Keokuk delivered the fair's first address. He hailed the fair as an event of historic significance, one that would mark the beginning of "an era in our history." Dixon predicted that the fair would immediately become one of the most powerful agents for developing the state's economy and ennobling its culture. The fair, he proclaimed, was the very heart of the state, drawing Iowans in from the hinterlands to revitalize them and send them homeward with a renewed appreciation of the dignity of agriculture. ${ }^{4}$

4. Dixon's address, befitting the occasion, was lengthy, filling 20 pages in Iowa State Agricultural Society (henceforth ISAS), Report, 1854, 27-48 (quotation from 27-28). On the first fair, see also Fairfield Ledger, 11/2/1854; and Iowa Farmer 2 (1854), 161. 
As a professional man, Dixon confessed his unfamiliarity with "the art of husbandry," but nonetheless proclaimed "some elemental truths." "The culture of the soil," he declared, "is not only the primitive calling of man, but it lies at the very bottom of the fabric of the useful arts and social advancement." Cultivating the earth distinguished civilization from savagery, and agricultural progress offered a sure index of any society's development. He quoted approvingly Massachusetts Senator Daniel Webster's stirring declaration: "When tillage begins, other arts follow. The farmers, therefore, are the founders of human civilization." The audience on the fairground undoubtedly nodded in agreement. History had a well-known plot, chronicling the steady development of civilization, which began when ancient people ceased to be nomads, hunters, and gatherers and began planting crops and domesticating livestock.

Ironically, most of the men who founded and led the Iowa State Fair were, like Dixon, not farmers. The Iowa State Agricultural Society's first president, Thomas Clagett, was publisher of the Keokuk Constitution, and its first secretary, Joshua M. Shaffer, was a physician who once confided to a friend that he knew "no more of farming than a hog does of fast day." ${ }^{\prime \prime}$ These men proudly identified themselves as "agriculturists" who sought to promote the development of scientific agriculture and economy by offering an extensive array of premiums and ribbons for livestock, crops, foods, crafts, and manufactures. Throughout the agricultural society's 46-year existence, businessmen, politicians, implement dealers, bankers, and professional men led the organization.

In its first three decades, the state fair had no permanent fairground, but moved to different locations in the eastern half of the state so that Iowans in different locales would have at least an occasional opportunity to attend the exhibition. As the fair's exhibits and attendance grew in size and railroads made travel to the fair much more feasible, it became desirable to create a permanent fairground. Thus, in 1879 the fair moved to Brown's Park in Des Moines, the state capital, which was centrally located and well served by railroads. It remained at

5. ISAS, Report, 1854, 28.

6. Joshua M. Shaffer to S. L. Smith, 11/28/1868, book 14:195, ISAS Papers, State Archives, State Historical Society of Iowa, Des Moines (hereafter cited as SHSI). 
Brown's Park until 1886, when the state government and the agricultural society combined to purchase the farm of Isaac Brandt, east of the city, to create a permanent fairground.

The annual state fair afforded the agricultural society its main opportunity to convey the tenets of scientific farming to the state's farmers. Its leaders were confident that the fair was among the most important agents of economic development in the state. They considered the society's annual convention, state fair, and yearly volume in assessing the important events and documents in the state's heritage. Acutely conscious of the history of their organization and fair, they were certain that a historian would eventually write their history, so they meticulously preserved their reports, minutes, and correspondence and hoped someday to create a museum to Iowa's agriculture and history on the fairground in Des Moines.

For these boosters, history told a tale of steady economic growth and scientific progress, in which fairs had played an indispensable role. The fair's organizers rightly insisted that fairs had contributed greatly to the development of European and American agriculture. They proudly traced the fair's lineage back to medieval Europe, where fairs originated as seasonal markets offering peasants and merchants an opportunity to congregate, barter, and revel. Like their European predecessors, American agricultural fairs were also marketplaces, but they were focused on promoting economic development and agricultural improvement by hosting competitions in which farmers vied to exhibit the finest livestock and crops. Competitors and spectators alike would learn by seeing the results of their neighbors' efforts, and they would contribute to further economic progress by striving to emulate or surpass the fair's prize-winning exhibits.

Accounts of the fair's history and the 1854 exhibition were staples of the fair's annual publicity campaigns. The agricultural

7. See A. P. Sandles (secretary, Ohio State Fair), "The Origin of Fairs," Billboard, 8/5/1911, 3; H. J. Aymer, "The Evolution of the Fair," ibid., 3/23/1912, 19; James M. Chaffaut (publicity director, Ohio State Fair), "The Changing Fair," ibid., 3/28/1931, 11. The foremost historian of American fairs, Wayne Caldwell Neely, in The Agricultural Fair (New York, 1935), esp. 251-64, espoused this evolutionary model, in which the fair continually evolved in response to new social and economic conditions. 
society offered a premium for the "Best History of the Fair," and often included the prize-winning account in its report. Scarcely a fair passed in the nineteenth century without an oration on the history of the society, tributes to its founders, and nostalgic recollections of past fairs.

In the late nineteenth century, the fair, and Iowans generally, became more retrospective, realizing that they now had decades of history to recount and preserve. Although virtually every fair offered patrons some lessons in Iowa's history, fairs held in anniversary years were especially steeped in Iowa's past. The inaugural fair on the permanent fairground in Des Moines in 1886, anniversaries of Iowa's accession as a federal territory (1888 and 1938) and state (1896 and 1946), the Closing Century Exposition of 1899, and anniversaries of the first fair (1904 and 1929), all emphasized historical themes. These anniversary fairs featured extensive displays of obsolete farm implements, kitchen tools, and other items that exhibitors were willing to haul from their sheds or attics to the fair. "Old Settlers" societies held meetings and picnics at the fair, inviting members of the pioneering generation to reminisce about frontier Iowa. Exhibits of rusted tools, old clothing, and other artifacts of frontier life tangibly reminded visitors how far their state had progressed and elicited sighs of relief at the relative ease and comfort of contemporary farm life compared to the hardship and privation of the pioneer era. History, in this instance, provided a sure gauge of the relative advantages of the present and foretold continued advances in the future. As the Homestead remarked aptly on the fair's fifty-fifth anniversary celebration in 1909, "never before were the possibilities of Iowa for the future so blended with the fulfillments of Iowa for the past."

8. For outstanding examples of addresses on the fair's history, see ISAS, Report, 1883, 81-97; ibid., 1886, 89-101. See also Peter Melendy's address before the society's annual meeting in January 1894, in ISAS, Report, 1893, 491-98.

9. Iowa Homestead 54 (1909), 1402-3. On the fair's increasingly backwardlooking exhibits in the 1890s, see G. H. Van Houten to L. H. Pickard, 3/7/1899, book 54:122-23, ISAS Papers. On the historical aspects of the 1904 fair, see the special fair section in the Des Moines Register and Leader (hereafter cited as DMREL), 8/21/1904, which includes accounts of the first fair, the fair's subsequent development, and "a prophecy" by Iowa State Board of Agriculture member S. B. Packard on "The State Fair of 1954." 
IN THE LATE NINETEENTH CENTURY, Americans commonly thought of their nation's history as a tale of steady progress. The United States steadily grew larger, more prosperous, more powerful. Upon lands that had formerly been wilderness, settlers built farms and communities. Scientific and industrial advances proceeded apace. Historian Frederick Jackson Turner offered the most famous version of this story of progress in a paper he presented at the American Historical Association's annual meeting in 1893. In "The Significance of the Frontier in American History," Turner staked out his influential "frontier thesis." According to Turner, encountering and subduing the raw wilderness on the frontier had transformed Europeans into Americans and furnished the source of Americans' individualistic society and democratic political system. Yet, as historians Andrew Cayton and Peter Onuf have perceptively noted, Turner's essay on the advance of civilization belied a nagging fear that the United States was on the brink of a substantial change, even decline. The 1890 federal census revealed that the frontier era had closed; with the rapid expansion of white settlement, no uninhabited land remained. Without the safety valve of western land, the nation would inevitably become more crowded and more urbanized. If the frontier were truly the source of American freedom, the nation's entire political system might be endangered. If Turner's frontier thesis was a tale of progress, that progress seemed to be imperiled, if not at an end.

During the early twentieth century, progressive, civic-minded reformers staged elaborate historical pageants to convey history to the public. Historian David Glassberg has noted that these widely popular pageants typically re-enacted historical episodes in an effort to imbue America's increasingly diverse population with a sense of shared heritage and belief in progress. These historical pageants embodied a tension between nostalgia for an idealized past and a forward-looking faith in the future. In the 1920s, as progressive reform subsided, nostalgia dominated

10. Frederick Jackson Turner, "The Significance of the Frontier in American History," in Proceedings of the Forty-First Annual Meeting of the State Historical Society of Wisconsin (Madison, 1894), 79-112; Andrew R. L. Cayton and Peter S. Onuf, The Midwest and the Nation: Rethinking the History of an American Region (Bloomington, IN, 1989). 
these pageants, which became focused on "the use of tradition as a bulwark against modernity."11

Although many Americans continued to view history as a story of political, economic, and social progress at the turn of the twentieth century, to some observers, progress soon came to appear anything but steady or certain. As historian Neil Harris has observed, America's rapid industrialization in the nineteenth and early twentieth century sparked a morbid fascination with disasters and accidents. As the nation industrialized, workplace accidents - on the railroads, in mines, in factoriesmultiplied. In the Progressive Era, proponents of "safety first" confidently insisted that proper study and precautions could reduce the incidence of workplace, railway, and highway accidents. Some Americans, however, suspected that the truth was contained in the simple phrase, "Accidents happen." The sinking of the Titanic in 1912 offered the era's most horrifying warning that even the most advanced technology was not immune to accidents. World War I provided a shattering lesson in the destructive potential of modern technology and upended many Americans' and Europeans' benign assumptions about the inevitability of progress."

In the early twentieth century, the fair's headline act was its nightly spectacle, staged before the fair's grandstand. Like the historical pageants produced by progressive reformers, these commercially produced spectacles featured enormous casts and lavish sets, but they added dazzling pyrotechnic displays reenacting some of history's most spectacular battles and natural disasters, almost invariably culminating in a blaze of pyrotechnical destruction. While the fair's agricultural exhibits continued to tally economic and scientific progress, the fair's new entertainments depicted sudden decline and wanton destruction. Disaster spectacles were among the most popular commercial entertainments in the United States from the turn of the century to the 1930s. Their widespread, long-running popularity attests to Americans' responsiveness to historical stories that suggested that progress had been purchased at a high cost and would not

11. Glassberg, American Historical Pageantry, 5, 258.

12. Neil Harris, "The Culture of Catastrophe" (unpublished paper presented at the University of Chicago, January 1984). 
continue indefinitely. As David Glassberg observes, Americans became more aware of history's discontinuities and the uncertainty of progress, especially after the searing experience of World War I. History seemed increasingly punctuated by sudden ruptures, reversals, and social upheavals of every sort: revolution, war, depression, technological innovation, and other precipitous, unpredictable changes. While the fair's exhibits remained devoted to fostering and measuring progress, its commercial entertainments bespoke this modern sensibility and its darker forebodings. Professional showmen offered a version of history that told a story not of progress but of catastrophe. Commercial disaster spectacles were starkly at odds not only with the fair's longstanding theme of steady improvement, but also with the civic-minded historical pageants commonly produced in communities across America during the Progressive era. ${ }^{13}$

FAIRS have always offered an occasion for festivity as well as for commerce and education, and the Iowa State Fair offered entertainments from its first exhibition in 1854. In the late nineteenth century, however, the size, expense, and popularity of the fair's entertainments grew, and all but the most austere agriculturists were compelled to concede that a fair without amusements would be a fair without customers. As a result, beginning in the 1880s, the fair's organizers began to book more entertainments for the annual fair in order to attract patrons, many of whom would not travel to the fair solely to look at exhibits of livestock or produce. In the 1880s and 1890s, the agriculturists who had founded the fair and oversaw it during its early decades were replaced by "fair men" who saw themselves not as scientists but as members of the growing outdoor entertainment business. As a result, entertainment became the fair's main attraction, without which it could not succeed.

The Iowa State Fair's first experience with a disaster spectacle proved a financial disaster for the fair. In 1893 the state fair was dwarfed by the gigantic World's Columbian Exhibition in Chicago, only 340 miles east of Des Moines, less than two hundred miles from the state's eastern counties, and easily accessible

13. Glassberg, American Historical Pageantry, 288. 
by rail. To compound the fair's problems, a devastating depression gripped the American economy in the spring of 1893. Competition from the world's fair, along with the deepening depression, led many of the society's officers to cast about for some novel means of boosting the fair's attendance.

That same year, Des Moines businessmen scheduled a tenday street festival to coincide with the fair. The festival featured The Last Days of Pompeii, a mammoth fireworks spectacle by the Pain Pyrotechnic Company of Chicago, "Sole Pyrotechnists to the World's Columbian Exposition." The agricultural society contributed to the cost of bringing the spectacle to Des Moines in the hope that the re-enactment of the eruption of Mount Vesuvius would attract crowds to the city, crowds that would almost certainly visit the fair. ${ }^{14}$ Pompeii enjoyed a wildly successful run in the city, but its popularity backfired on the fair, siphoning off its nighttime crowds. (The fairground had been equipped with electric lights only the previous year, making possible nighttime events at the fair.) The 1893 fair lost so much money that the agricultural society found itself unable to pay premiums to its prize-winning exhibitors, a source of great embarrassment to the society. Buried in debt by the depression and by the cardboard volcano, the fair's officers had at least learned an important lesson from Pompeii. In the future, they vowed, such spectacles would be staged on the fairground. The legacy of the Chicago world's fair of 1893 transformed state and county fairs throughout the United States, accelerating the growth of entertainments at fairs big and small. In the wake of the world's fair, the outdoor amusement industry boomed, and state and county fairs created their own "midways," in imitation of the celebrated entertainment zone at the world's fair. ${ }^{15}$

14. ISAS, Report, 1893, 114; John R. Shaffer (JRS) to John A. Evans, 7/19/1893, book 46:136, ISAS Papers; JRS to Joshua M. Shaffer, 7/25/1893, ibid., 176; JRS to O. E. Skiff, 7/27/1893, ibid., 193; JRS to John A. Evans, 8/5/1893, ibid., 268; JRS to John A. Evans, 7/7/1893, ibid., 270.

15. Iowa State Register, $8 / 30 / 1893$; see also ibid., $8 / 31 / 1893$ and $9 / 1 / 1893$. On the addition of electric lighting in 1892, see ISAS, Report, 1889, 635; ibid., 1890, 653 ; ibid. 38 (1891), 132. On the 1893 fair's disappointing receipts, see the Iowa State Register, 9/8/1893 and 9/9/1893. The fair's receipts for 1893 totaled $\$ 25,435$, less than half the amount of each of the previous four years. 
TO-NIGIT, SEPT. 1, FIFTH NIGIIT OF THE CARNiVAL, FIREWOKKS AMPHITHEATRE-Ati 1.tis Park. Fout of 7th st.
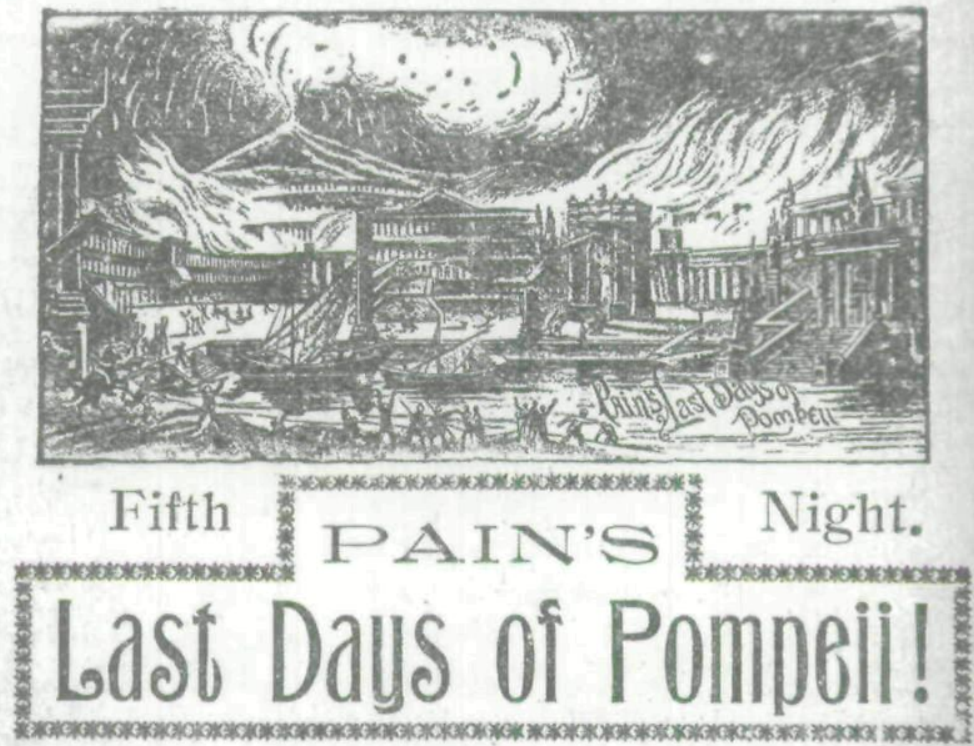

Ladies' Night.

GRAND FIRE PORTRAIT OF THE HANDSUM CST LADY IN TIIE CITY. All the many wonders of the great exhibit complete in every detal. Be sure and wi a s: the STARTLANG ERU IIOS OF V

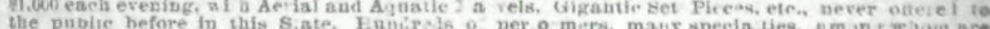
the pnblic before in this S.ate Hancrels o per o mers. mans speela ties, among waou are ean we tem in. the greatest high wire equinbrist in the wo:ta.

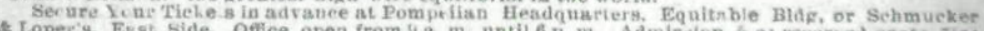

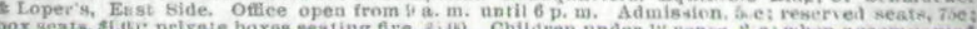

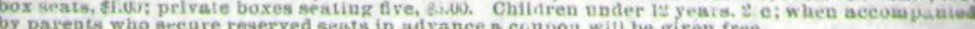
[ N. B.-Fon't forget to vote for the handsomest lady on Ladies' Night, Sept. 1.

This advertisement in the Des Moines Register, 9/1/1893, promoted "Ladies' Night" at the Last Days of Pompeii spectacle in the city.

Unfortunately, the financial depression persisted until 1897, and the Iowa State Fair remained mired in debt and unable to book large shows and amusements, which were simply too expensive. In 1899 the fair's secretary had an idea for an inexpensive exhibit to attract crowds. He grandly billed the fair as the "Closing Century Exposition." It featured exhibits of obsolete implements and other relics from the pioneer era, as well as historical exhibits designed to "show the development to the present time." The exposition's advertisements boasted that it furnished "an interesting contrast between the appliances, 
processes and methods of life today, and those of the earlier years of the century." The fair's growing devotion to the past attested to a growing awareness of the state's history, which was now long enough to enable citizens to look backward and take stock of the progress made since the pioneer era. ${ }^{16}$

The Closing Century Exposition earned a profit, but the fair's economic woes in the 1890s forced the leaders of the State Agricultural Society to concede that their organization simply lacked the resources to host a suitably attractive fair, maintain and improve the extensive fairground, and dependably meet its expenses. In 1900 the state legislature voted to revoke the Iowa State Agricultural Society's charter and transfer the fair to the State Board of Agriculture (soon dubbed the fair board), a division of the newly created State Department of Agriculture. In 1923 the legislature transferred responsibility for the fair to the Iowa State Fair Board, which has managed the fair since. ${ }^{17}$

For the 1902 fair, the new fair board booked a gargantuan disaster spectacle, the Pain Pyrotechnic Company's The Last Days of Pompeii. Edward Bulwer-Lytton's novelistic account of the eruption of Mount Vesuvius, The Last Days of Pompeii, published in 1834, had proved a sensational and durable success throughout the nineteenth century, impressing upon readers the power of unforeseeable fate to lay waste to humans' plans and, in BulwerLytton's telling account, to punish misdeeds. The pageant's extraordinary popularity with fairgoers led the fair's organizers to book another Pain Company pageant, Ancient Rome, which depicted the city's burning under the Emperor Nero, for the 1903 fair. For the next three decades, gigantic pyrotechnic spectacles headlined the fair's bill. ${ }^{18}$

These spectacles were popular in part because spectacle producers staged eye-popping extravaganzas, which dazzled

16. ISAS, Report, $1897,117$.

17. Laws of Iowa, 1900, 40-41. The Iowa State Agricultural Society's final report and minutes are included in the Iowa Year Book of Agriculture (hereafter cited as Year Book), 1900, 174-90. For an account critical of the society that hails its replacement by the State Board of Agriculture, see the DMREL, 8/21/1910, Exposition Number, p. 2.

18. B. E. Gregory (of Pain Pyrotechnic Company) to J. C. Simpson, 5/14/ 1902, box Sat 1, folder 7, State Board of Agriculture Papers (hereafter cited as SBA), State Archives, SHSI; DMREL, 8/21/1902, 8/25/1902, 8/27/1902, 8/22/1903. 
viewers with enormous casts, elaborate scenery, and amazing fireworks. Audiences could scarcely fail to be impressed by these nighttime extravaganzas, which dwarfed any stage show or fireworks display they had seen in their hometowns. One woman, recounting her first trip to the fair, admitted, "I can't remember a single thing that I saw except the night show! The Last Days of Pompeii was being produced, and I sat on the edge of a narrow, hard old board, utterly lost in rapture-there was so much beauty, so much action, so much color, so much grandeur, in the setting against which the story moved to its spectacular and tragic conclusion with the eruption of Mount Vesuvius and the destruction of the city there at the water's edge!" Even the Breeder's Gazette, a livestock journal often critical of the growing prominence of entertainments at fairs, confessed in 1909, "It is easy to contract the night-show habit at these fairs." ${ }^{19}$

But spectacles were not merely grandiose: they told an unambiguous morality tale, in which progress and frivolity ultimately culminated in destruction. Performed before an enormous grandstand without electronic amplification, these spectacles contained no dialogue, although the show's program sketched out a synopsis of the plot to guide spectators. In order to be intelligible at all, spectacles depicted clear-cut struggles between good and evil. Whatever their ostensible subject, these spectacles shared a common motif-pyrotechnists thrived on utter destruction, and the finale of nearly every spectacle entailed leveling the set and everything on it. The civilizations annihilated before the fair's amphitheater were typically great cities bustling with festivity in their last moments before disaster struck. These spectacles clearly conveyed the moral that the frenetic pace and frivolity of urban life were perilous, even wicked, and that they would ultimately provoke retribution. In short, commercial grandstand spectacles, which were immensely popular at state fairs across America from the 1890 s into the 1930s, presented a version of history at odds with the paeans to progress invoked annually by the fairs' organizers.

Pyrotechnic companies typically produced only a few spectacles each year and took these shows on the road to fairs around

19. Minutes, State Agricultural Convention, 1938, in Iowa State Fair Board, Annual Report, 1938, 177-78; Breeder's Gazette (Chicago), quoted in Year Book, 1909, 660. 
the nation. Although these spectacles were not created specifically for midwestern or rural audiences, fairgoers likely drew their own particular lessons from them, lessons shaped by the same tensions that swirled around the fair and around Iowa for decades as a rural, agricultural state came to terms with a rapidly urbanizing and industrializing nation. As historians Don Kirschner and David Danbom have noted, rural Americans were not effortlessly reconciled to urbanization, and they resented the declining status of farming..$^{20}$

Most disaster spectacles recreated historic battles and natural disasters - often embellished to dazzle the audience-and culminated in a blaze of destruction that swept the entire stage. Many of the spectacles based on historic battles were unabashedly nationalistic, even jingoistic, and celebrated American military triumphs. In 1913 the audience in the state fair's grandstand witnessed a re-enactment of General Winfield Scott's capture of Mexico City in 1847, supplemented by a volcanic eruption of nearby Mount Popocatapetl just as the battle for the Mexican capital reached its height. As the spectacle opened, Mexican citizens joyously celebrated a feast day with dancing, bullfights, cockfights, and gambling, only to be annihilated by the combined force of American troops and molten lava. The 1928 fair presented the Battle of Manila, which commemorated the thirtieth anniversary of Admiral Dewey's crushing defeat of the Spanish fleet in the Philippines. ${ }^{21}$

Ancient battles also provided the inspiration for disaster spectacles. In 1927 The Fall of Troy filled the fair's stage. Taking literary license with Homer's epic tale, the production required "an army of pyrotechnicians" and culminated with "an entire city blown up before your eyes." In 1921 the fair staged Montezuma, which featured a battle between the great chieftain's Aztecs and Cortez's conquistadors. As usual, the destructive ca-

20. Don Kirschner, City and Country: Rural Responses to Urbanization (Westport, CT, 1970); David B. Danbom, The Resisted Revolution: Urban America and the Industrialization of Agriculture, 1900-1930 (Ames, 1979). See also James Shideler, "Flappers and Philosophers and Farmers: Rural-Urban Tensions of the Twenties," Agricultural History 47 (1973), 298.

21. DMREL, 8/23/1913, Fair magazine, p. 6; Iowa State Fair Board, Official Catalog, 1913, 30, 33-35, 46-49; Greater Iowa, 8/15/1913, 8; ibid., May 1928, 5; Des Moines Register (hereafter cited as DMR), 8/24/1928, 8/25/1928. 


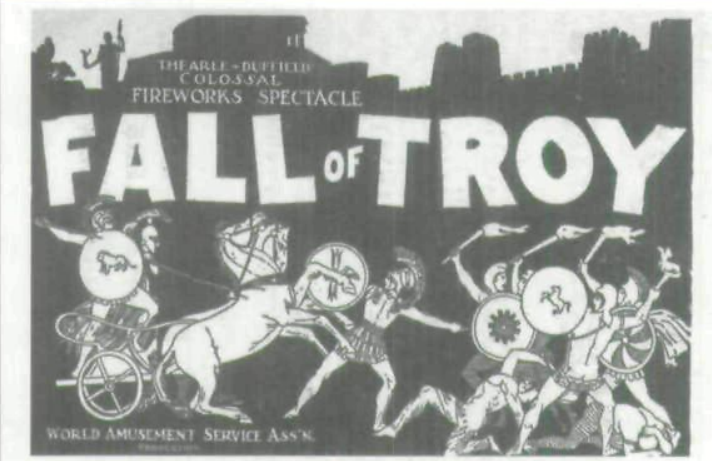

The Feature Entertainment

EVERY

NIGHT

At the

\section{Iowa State Fair}

An advertisement for The Fall of Troy in the Iowa State Fair Board's Premium List, 1927, 237.

pacity of conventional weapons proved insufficient to satisfy the tastes of the spectacle's creators, who added the usual volcano and an earthquake to complete the annihilation of the Aztecs' civilization. ${ }^{22}$

Renowned disasters, like battles, lent themselves nicely to the pyrotechnist's art, and commonly told a morality tale in which decadence culminated in disaster. Vesuvius erupted repeatedly on the fairground, burying Pompeii in 1902, 1907, 1911, 1916, and 1929, allowing countless Iowans to vicariously experience history's best-known natural catastrophe at least once. In these spectacles, as in Bulwer-Lytton's book, the volcanic eruption seemed not so much a natural disaster as an outburst of moral retribution against excessive frivolity, as decadence invariably provoked catastrophe. The 1916 production of the Last Days of Pompeii, for instance, opened to reveal Pompeii "in all its ancient splendor on a fete day, with its crowded streets, gladitorial combats, races, games, Egyptian dances and other forms of merrymaking," until Vesuvius erupts, "burying the city with its profligate people. ${ }^{\prime 23}$ In 1903 the fair presented The Fall of Rome, depicting the city's burning under Emperor Nero.

22. Greater Iowa, April 1927, 2; Official Catalog, 1927, 25; DMR, 8/19/1927, 8/27/1927; Greater Iowa, June 1921, 8; Iowa Homestead 66 (1921), 353.

23. Greater Iowa, 8/19/1911, 6; DMREL, 8/20/1911, special State Fair section, p. 3; ibid., 8/30/1911; Year Book, 1916, 9; Greater Iowa, July 1916, 5; Official Catalog, 1916, 35; DMREL, 8/20/1916; Iowa Homestead 61 (1916), 1418 (quotation). 
The disaster was repeated in 1925 as Rome Under Nero, which advertisements boasted was surpassed "only by the original burning of Rome Under Nero." "Every effort has been made to keep the presentation of the production accurate both as to realistic scenic effects and to historical truth. ${ }^{124}$

Spectacles sometimes enabled the audience to "witness" recent battles and other momentous events that they would otherwise be able only to imagine. In 1905, for instance, the fair's managers booked a recreation of the Japanese attack on the Russian naval base at Port Arthur the previous year. In 1914, shortly after the completion of the Panama Canal, the fair's nighttime entertainment featured The Opening of the Panama Canal and Uncle Sam's Reception to the World. Billed as "a realistic, scenic production," the spectacle boasted 300 cast members on a 400foot stage. After a lavish ceremony to mark the canal's official opening, Panama suddenly became the scene of "a gorgeous pandemonium of cannonading and multi-colored fire," as ships in the canal, troops on its banks, and aircraft circling overhead all began to do battle. The eruption of a nearby volcano (nowhere to be found in the topography of the real Panama) supplemented the aerial and naval bombardments, destroying all the buildings alongside the waterway and the ships in it. The spectacle's finale was titled "Uncle Sam at Peace with the World," but when the smoke finally cleared, "the whole festive scene had been shot, blown, and burned to fragments. ${ }^{25}$

From 1915 to 1920 , World War I furnished the basis for the fair's spectacle, as producers staged recreations of major European battles. Pyrotechnists and fair managers alike promised the fair's patrons that these "living tableaux" would afford them an understanding of the war's horrors that could otherwise be gained only by witnessing the battles in person. Newspaper accounts of the war, the fair's advertisements declared, were a feeble substitute for seeing, because "pictures appeal

24. DMREL, 8/22/1903, 8/25/1903; Greater Iowa, April 1925, 3; ibid., June 1925, 5; DMR, 8/27/1925, 8/28/1925.

25. J. C. Simpson to W. W. Morrow, 5/22/1905, J. C. Simpson to C. E. Cameron, 5/22/1905, W. W. Morrow to J. C. Simpson, 5/23/1905, all in box Sat 3, folder 21, SBA Papers; DMREL, 8/28/1905; Year Book, 1905, 156, 159; ibid., 1914, 44; Official Catalog, 1914, 92-95; DMREL, 8/28/1914, 8/29/1914 (quotation). 


\section{THE WORID'S GREATEST OPEN AIR THE WULLU GHEAIES EXHIBBTTOON} TOO BIG FOR TENT OR ROOF, HEAVEN'S LOFTY DOME ITS ONLY CAMOPY

EVERY EVENING

In front of the New Steel Amphitheater

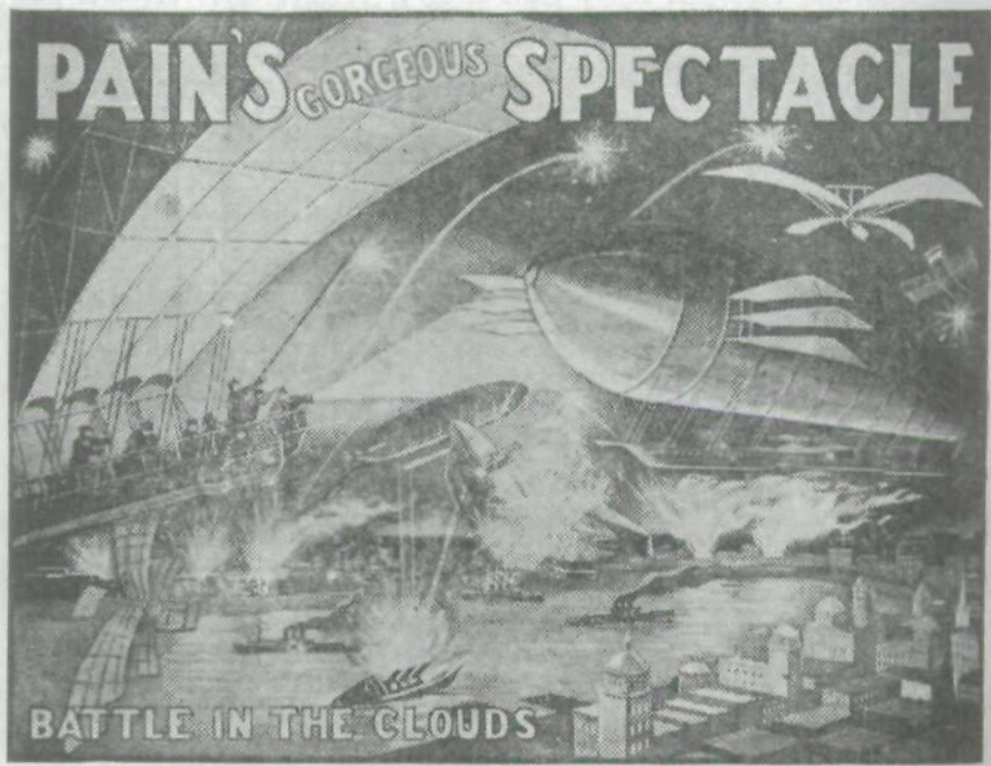

Depicting how the modern air ship will be used to raze cities and destroy whole armies in future wars

Each performance terminates with a beautiful dis= play of Pain's Fireworks

\section{.....NEW FEATURES LARGER AND BETTER THAN EVER....}

An advertisement for Battle in the Clouds in the State Fair's Official Program, 1909.

with peculiar force and significance." In 1915 the fair staged The War of Nations, which revealed the horror of modern weaponry. The fair's grandstand shows for 1917 and 1918, Modern Warfare, or an Attack on the Trenches and World's War, echoed the antiGerman tenor of the U.S. government's wartime propaganda, railing against the barbarities of German aggression against 
French and Belgian villages and concluding with rousing musical numbers and pyrotechnic displays of patriotism. ${ }^{26}$ Despite the bravado of these spectacles, the real war's ghastly death toll blasted many Americans' and Europeans' presumption that their societies were the world's most civilized, and that technology and economic prosperity guaranteed social and moral progress.

Pyrotechnists occasionally staged entirely fantastic spectacles, but even these imaginary scenes spoke to Americans' fears about the destructive potential of technology and the likelihood of catastrophe. In 1909 spectators in the fair's newly constructed grandstand witnessed the Pain Company's Battle in the Clouds, inspired by H. G. Wells's science fiction novel, War in the Air (1908), which warned of the threat posed by modern technology. A description of the pageant in the fair's Official Program chronicled its plot: in the year 2000, while citizens of "Centaerial," a utopian "city of science," celebrate the anniversary of a decisive aerial victory, their city is suddenly attacked by enemy airships. Troops loyal to King Pyro, "ruler of the world of science," fight valiantly in self-defense, but are machine-gunned by the invading craft, which ultimately reduce their city to a pyrotechnic "fire of all colors." According to the fair's advertisement, the production allowed viewers to glimpse "the possibilities of future warfare in the skies," revealing "how the modern airship will be used to raze cities and destroy whole armies" with machine guns and bombs. Human ingenuity soon confirmed, and even exceeded, this frightening vision of the future. ${ }^{27}$

26. Year Book, 1915, 8; Greater Iowa, August 1915, 3; DMREL, 8/23/1915, 8/26/ 1915; Official Catalog, 1915, 38; ibid., 1917, 35; DMR, 8/25/1917; Greater Iowa, September 1917, 2; Year Book, 1917, 76-77; DMR, 8/24/1918; Year Book, 1918, 10; ibid. 1919, 13; Greater Iowa, March 1918, 8. The following year, The Grand Scenic Military Spectacle, The Battle of Chateau Thierry, recreated a decisive but costly Allied victory. In the daytime, while the fairground enjoyed a temporary ceasefire, workers scrambled to reconstruct the spectacle's demolished 450 -foot set in time for the evening's performance. In 1920 the fair recreated one of the war's earliest battles, the Allies' naval Siege of the Dardanelles. DMR, 8/20/1919, 8/23/1919, 8/24/1919; Iowa Homestead 64 (1919), 1956, 1972; DMR, 8/28/1920.

27. Greater Iowa, May 1909, 1; ibid., 8/14/1909, 6; Official Catalog, 1909, 18; Year Book, 1909, 228; DMREL, 8/20/1909, 8/29/1909. After much deliberation, the board selected Battle of the Clouds over Night Riders of Kentucky, which depicted a band of Klansmen on a rampage of lynching and arson that destroys an entire town before the state militia arrives and "the strong arm of the Government triumphs." F. M. Barnes to J. C. Simpson, 4/14/1909, box Sat 6, folder 56, SBA 


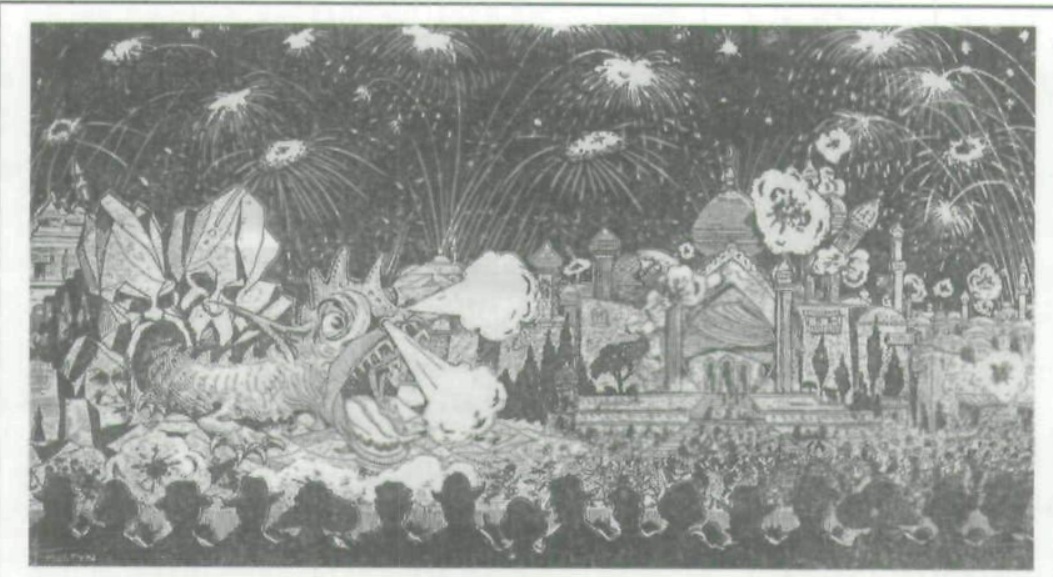

A sketch depicting A Night in Baghdad in Greater Iowa, May 1928.

Only once did the fair's spectacle recreate an event from Iowa history. In 1910 the fair booked a pageant about one of the most shocking episodes in the history of the frontier state. The Pain Company's dramatization of The Spirit Lake Massacre of 1857, in which a renegade band of Sioux Indians killed 34 settlers, characteristically embellished the story, exaggerating the number of settlers and American Indians involved and inserting a brigade of U.S. Cavalry into the fray, although no volcanoes were added to the relatively gentle Iowa landscape. ${ }^{28}$

Spectacles were often racist and jingoistic. Many spectacles culminated with the destruction of another, usually non-Western, civilization, pandering to white Americans' presumption of superiority to other cultures in an era in which the United States rapidly emerged as the world's wealthiest and most powerful nation. In the 1920s the fair's main attractions included Mystic China, Tokyo through Quake and Fire, India, and A Night in Baghdad, all of which climaxed with the annihilation of exotic, bustling civilizations. After the spectacle's set had been reduced to smoldering rubble, the pyrotechnic grand finale always in-

Papers; J. C. Simpson to C. E. Cameron, 4/15/1909, ibid., folder 58; C. E. Cameron to J. C. Simpson, 4/19/1909, ibid; Greater Iowa, May 1909, 1; ibid., 8/14/ 1909, 6; Official Catalog, 1909, 18; Year Book, 1909, 228; DMREL, 8/20/1909, $8 / 29 / 1909$.

28. Year Book, 1910, 301, 303; Greater Iowa, May 1910, 1; ibid., 8/12/1910, 2; DMREL, 8/21/1910, Exposition number, p. 5 . 
cluded several patriotic set-pieces (images outlined by fireworks mounted on wooden scaffolds) depicting the American flag and other national icons. ${ }^{29}$

Still, it would be too simplistic to view these spectacles solely as jingoistic tableaux of American or Anglo-Saxon superiority. Spectacles could be nationalistic, xenophobic, even outright racist, yet simultaneously suggest misgivings about the ability of any civilization to stave off corruption and decline. Reenactments of the sudden, inescapable destruction of thriving civilizations could hardly fail to remind many members of the audience that even the world's greatest empires ultimately succumbed to decay, defeat, or destruction. Was the United States hurtling toward a similar fate? These cataclysmic spectacles suggested that progress sometimes exacted too great a price, and that profligacy culminated in disaster. While the fair's exhibits tallied inexorable progress, the fair's headline entertainment displayed sudden, seemingly inescapable decline and destruction and suggested a sense of history anything but confident.

In an era in which many Americans understandably fretted about the vast changes rapidly transforming their nation, witnessing the corruption and sudden, violent demise of vibrant civilizations not only allowed spectators to gape at others' misfortune, but bespoke a nagging perception that their own society might be hurtling toward a similar fate. The horror and disillusionment of World War I and the pitched battle between rural and urban America in the 1920s only exacerbated some Americans' foreboding about the price of progress. Not coincidentally, disaster spectacles, with their blunt morality tales about the pitfalls of progress, reached their peak popularity in the 1920 s, a moment of particularly strident controversy between rural and urban America, as a rural society devoted to agricultural production confronted the emergent culture of an urbanized, industrialized, and consumption-oriented society. ${ }^{30}$

29. Year Book, 1922, 2; Official Catalog, 1922, 61; Greater Iowa, July 1922; ibid., May 1923, 6; DMR, 8/24/1923, 8/25/1923; Greater Iowa, May 1928, 5; DMR, $8 / 24 / 1928,8 / 25 / 1928$.

30. For an excellent overview of the 1920s, see Lynn Dumenil, The Modern Temper: American Culture and Society in the 1920s (New York, 1995). On the tensions between farmers and city dwellers, see note 20 . 
IN 1929 the Iowa State Fair commemorated decades of growth by celebrating its seventy-fifth anniversary "Diamond Jubilee." The fair board arranged for an extensive array of historical exhibits and erected yet another cardboard Vesuvius to stage a new production of Pompeii, billed as the "greatest, most appalling fireworks spectacle of all time. ${ }^{{ }^{31}}$ Although farmers suffered difficult economic times in the 1920s as the price of commodities tumbled after World War I, the state fair remained consistently profitable throughout the decade. The "Diamond Jubilee" fair of 1929 capped a decade of success by setting the fair's all-time attendance record and generating a substantial profit. Afterward, fair secretary Arthur Corey observed that the historical exhibits "attracted the interest of tens of thousands, who would not have cared to see 'just another state fair."

These visitors did not look to the past only to shake their heads in wonder at the difficult life endured by their pioneer forebears or to marvel at the advent of telephones, tractors, and indoor plumbing. As Iowa writer Ruth Suckow observed in 1926 , over the previous two decades, Iowans had begun to recognize that their state now possessed a history and culture worthy of consideration. Iowans, and midwesterners generally, had begun to shake off their nagging sense of cultural inferiority to the East and to assert that the Midwest now had its own indigenous culture built atop its prodigious agricultural productivity. Surveying the fair, Wallaces' Farmer observed approvingly that Iowans were "becoming increasingly conscious and increasingly proud of the past of their state" and were keenly interested in the fair's extensive historical exhibits. These exhibits bolstered the fair's reputation for seriousness of purpose and earned the approbation of even the editors of Wallaces' Farmer and the Iowa Homestead, both of which consistently urged the fair board to emphasize educational exhibits and reduce the number of midways, shows, and other entertainments. ${ }^{33}$

31. Greater Iowa, April 1929, 7; ibid., July 1929, 2; DMR, 8/24/1929; Wallaces' Farmer 54 (1929), 1133; Iowa Homestead 74 (1929), 1336.

32. Billboard, 6/14/1930, 47

33. Ruth Suckow, "Iowa," American Mercury 9 (September 1926), 39-45; Greater Iowa, October 1929, 5, 6; Wallaces' Farmer 54 (1929), 1189; Iowa Homestead 74 (1929), 1166, 1174, 1209, 1291; Bureau Farmer 4 (Iowa edition) (August 1929), 17. 
Less than two months after the 1929 fair closed, a real calamity befell Americans when the collapse of the stock market marked the onset of the Great Depression. Showmen and fair men, irrepressible optimists, gamely planned for the 1930 fair despite the depression, insisting that Iowans cherished their annual fair so deeply that the depression would not keep them home during fair week. The annual fair was scarcely proved "depression proof," however, and its attendance and profits plummeted over the next few years.

Perhaps fittingly, in 1930 the fair's last grand commercial spectacle pronounced a harsh verdict on the end of the jazz age. In 1930 the Thearle-Duffield Fireworks Company audaciously attempted to chronicle "the entire course of world history" in The Awakening, a spectacle that declared unequivocally that "progress" had gone too far. The gargantuan spectacle began with the "awakening" of life in the Garden of Eden, then portrayed, in turn, Roman orgies and the persecution of Christians under Nero (the awakening of evil), Columbus's discovery of the New World (the awakening of the New World), the American Revolution (the awakening of independence), and the Civil War (the awakening of freedom). In the 1920s the awakening of a new evil, "the spirit of jazz, unrest and laxity of living" heralded the next epoch in this sweeping overview of the history of Western civilization. Jazz dethroned the spirit of Beauty, provoking Americans to "throw themselves into an orgy of abandonment," hedonism, and drinking, until a pyrotechnic "outburst of the heavens against that spirit" squelched the jazz orgy. ${ }^{34}$

After a run of some thirty years, grandstand spectacles quickly declined in popularity, as radio and movies transformed American popular culture and the financial disaster of the depression made staged disasters far less appealing. As historian Warren Susman has observed, amid the economic troubles and political uncertainty of the 1930s, many Americans sought reassurance in their nation's past and searched for signs that prosperity and stability would return in the future. Amid the economic wreck of the depression, audiences no longer took

34. Greater Iowa, August 1930, 4; Official Catalog, 1930, 22-23; DMR, 8/23/1930. Phil Stong lampooned The Awakening in his novel, State Fair (Philadelphia, 1932), 112-15. 
delight in spectacles that culminated in sudden ruin. Just as screwball comedies replaced gangster films on the movie screen in the 1930s, musical revues replaced disaster spectacles on the fair's stage. The growing popularity of movies also helped to doom the spectacles. Now that most Iowans could see and hear historical and dramatic films at their local theater, gigantic stage shows no longer seemed dazzling, but downright ponderous, and these dinosaurs of the show world quickly succumbed to extinction. The economic downturn left the fair board unwilling and unable to book lavish, expensive grandstand shows, forcing it to rely instead on smaller acts, such as song-and-dance variety shows, which were less expensive and seemed more contemporary in an era in which radio and movies had rapidly reshaped American popular entertainment. ${ }^{35}$

Just as the depression impelled some Iowans to look backward and seek reassurance in their history, it inspired the fair board to resuscitate time-honored agrarian rhetoric hailing the fair's central agricultural mission. The present was not a pretty sight, filled as it was with bread lines, labor strife, abandoned farms, and embittered farmers. But the nation's history, its remarkable growth and its ability to persevere through the American Revolution and the Civil War, suggested that the republic would endure and that good times would someday return. "The Iowa State Fair feels a stern responsibility in times such as these," the 1931 Premium List declared, adding that the fair would include entertainment but would be designed "primarily as a place to go to school." The following year, the fair board urged "the rehabilitation of agriculture, and the restoration of the farmer to his rightful place in the economic world," promising that the exhibition would be "a farmer's fair" and "an 'old fashioned' State Fair," one that aimed above all else to educate its visitors. In 1933 the board proclaimed "Back to Fundamentals"

35. Warren I. Susman, "The Culture of the Thirties," in Culture as History (New York, 1984), 150-83; Robert Sklar, Movie-Made America: A Cultural History of American Movies (New York, 1975), 175-94. In 1931 and 1932 the fair booked variety shows that were an odd mixture of music and travelogue, affording the audience glimpses of various cities, cultures, and festivities around the globe. Greater Iowa, May 1931, 4; ibid., August 1931, 4; Official Catalog, 1931, 22-24; DMR, 8/30/1931; Greater Iowa, June 1932, 5; Official Catalog, 1932, 21-23; DMR, $8 / 26 / 1932,8 / 27 / 1932$. 


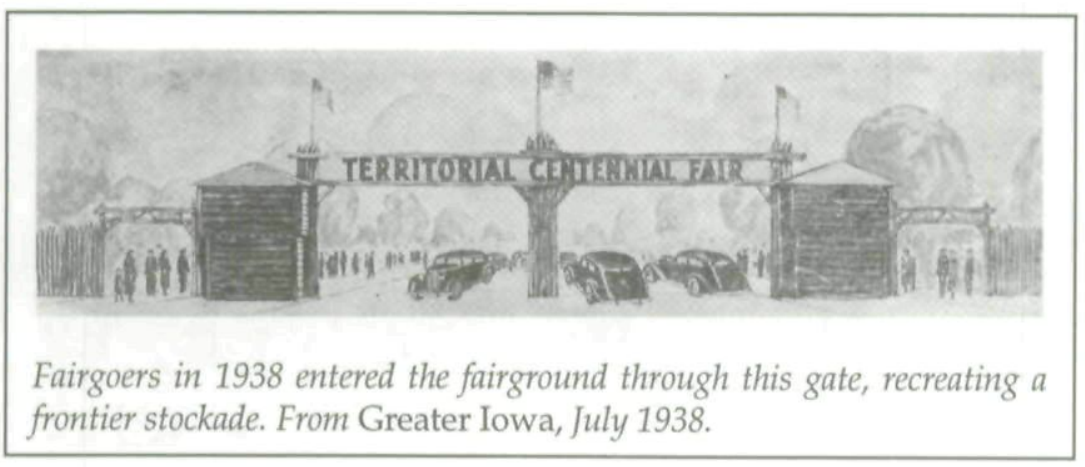

as the fair's slogan, insisting that "the time has come for agriculture to return to the proven principles which gave our farm regions their first development and prosperity." Hard times impelled midwesterners, like other Americans, to look to their past for the "proven principles" that had formerly made their agricultural economy prosperous and lent the fair its sense of high purpose. $^{36}$

In the 1930s the appeal of this agrarian rhetoric stretched far beyond Iowa. At the depths of the depression, Iowa native Phil Stong scored a best-seller with his novel, State Fair (1932), which depicted a happy, likeable farm family, the Frakes, and their annual sojourn to the fair. Stong's novel suggested that farmers were not beaten down by the depression but were irrepressibly optimistic. Although the Frakes enjoy their week in Des Moines at the fair, they do not crave its excitements enough to even consider abandoning farm life. In Stong's novel, farm families are rooted in a particular place, inextricably attached to their land, and profoundly connected to their forebears and their descendants. Their seemingly timeless existence, governed by the recurrent cycle of planting and harvesting, seems almost impervious to the enormous changes remaking American culture in the 1920 s and early 1930s. The novel virtually discards any notion of historical change by suggesting that farmers lived almost wholly outside of time. As such, the novel, and the subsequent Fox Studio film (1933), resonated with Americans eager to

36. Iowa State Fair Board, Premium List, 1931, 7. In 1931 the ravages of the depression hit with full force, and the fair lost more than $\$ 63,000$; in 1932 it lost $\$ 67,000$. Official Catalog, 1932, 9; Greater Iowa, April 1932, 2; ibid., May 1933, 2. 


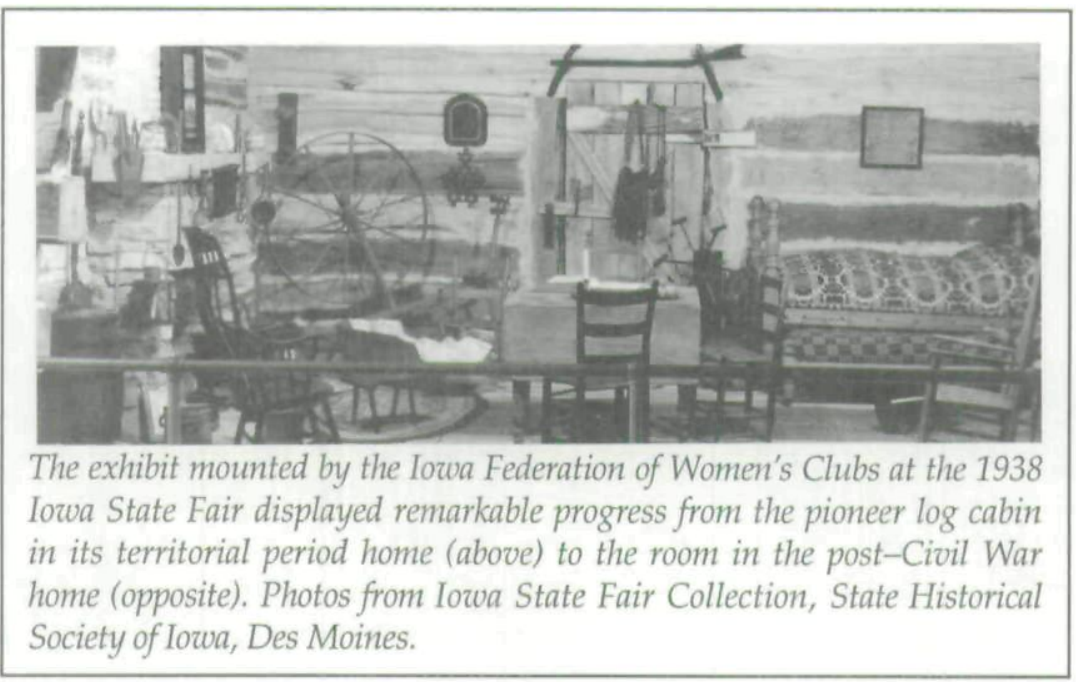

believe that farmers would not only endure the depression but would somehow enable the entire nation to survive it as well. ${ }^{37}$

By far the fair's most ambitious historical exhibit appeared amidst the Great Depression in 1938 to commemorate the centenary of Iowa's accession as a federal territory. After passing through a gate designed to resemble a frontier stockade, fairgoers discovered an extensive centennial celebration, including exhibits on virtually every aspect of Iowa's past, ranging from the development of farm implements and livestock breeding to household interiors. "Never before," the fair board's secretary declared, "has Iowa presented at any one time or place such a comprehensive historical story of her progress and achievements in farming, industry and cultural pursuits." The Iowa Federation of Women's Clubs created an extensive exhibit that recreated four household interiors ranging from the pioneer era to the 1930s, filled with household items and women's fashions from each period. The 1938 fair featured a home-grown historical pageant, the Cavalcade of Iowa. Billed as "the crowning event" of the centennial, Cavalcade traced the state's history from the expedition of the French explorers Joliet and Marquette in the 1670s through the Louisiana Purchase, expulsion of the Indians, statehood, and Civil War, culminating with the arrival of the "horse- 


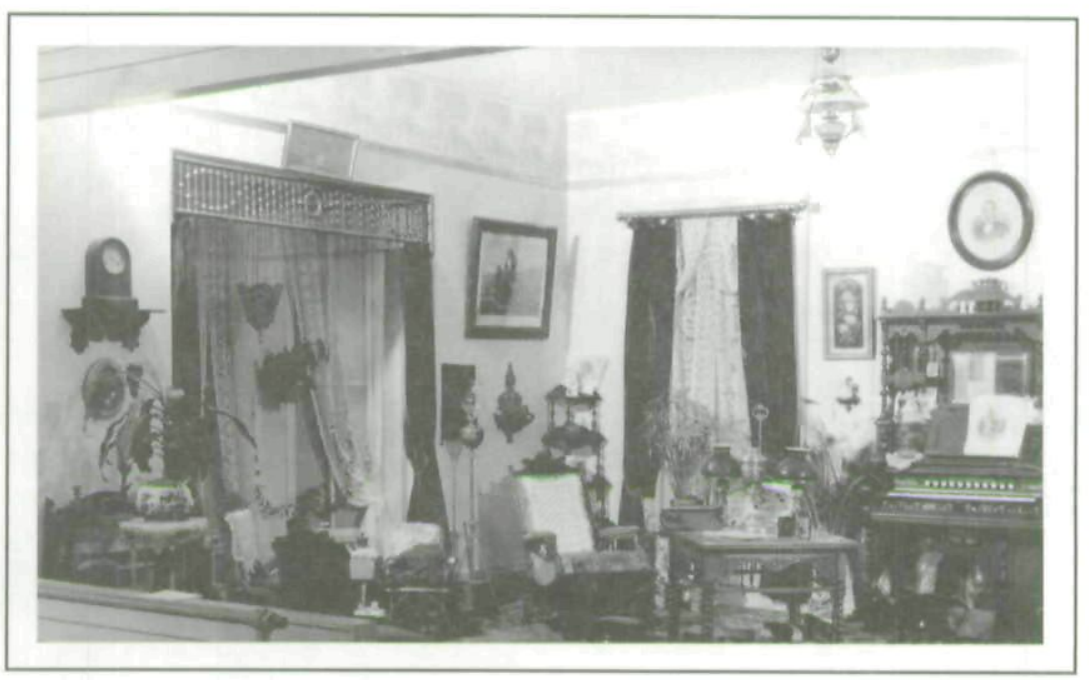

less carriage" and the airplane. The pageant recreated the first state fair of 1854, complete with loud, gaudy sideshows and a re-enactment of the highlight of the inaugural fair, a wildly popular and controversial ladies' equestrian contest, in which young women vied for the title of Iowa's best female rider. Cavalcade's story of economic and technological progress reprised the nineteenth-century frontier myth, in which civilization advanced steadily through a series of stages from the frontier to a fully developed, industrialized society. ${ }^{38}$

The 1938 fair also marked the debut of another epic depiction of Iowa's history, as regionalist painters Daniel Rhodes and Howard Johnson unveiled their 218-foot WPA mural of Iowa's history in the Agriculture Building-the epicenter of the fair's exhibits of Iowa's economic bounty and progress. The enormous painting provoked enormous controversy. In the 1930s, as some midwestern painters sought to create an indigenous culture, they began to depict local subjects and landscapes rather than look to Europe for artistic inspiration. Iowan Grant Wood, along with

38. Iowa State Fair Board, Minute Book, 1937-1940, Iowa State Fairgrounds, Des Moines, 28-30, 70; Iowa Territorial Centennial Committee, "Proposal for Iowa Centennial," 1938, SHSI; Premium List, 1938, 7; Iowa State Fair Board, Annual Report, 1938, 5 (quotation). On the historical pageant, see the souvenir program, "Cavalcade of Iowa," SHSI; "Cavalcade of Iowa," typescript, SHSI; Greater Iowa, August 1938, 5; Official Catalog, 1938, 43-44; DMR, 8/25/1938. 


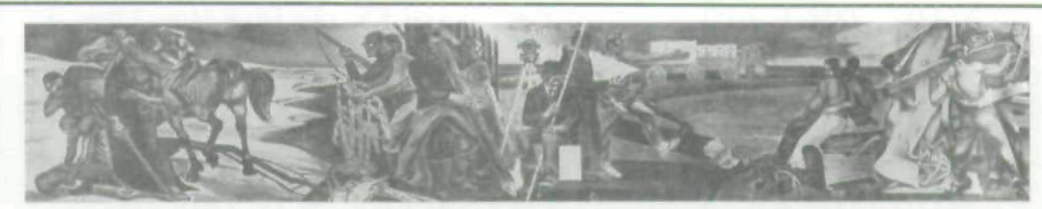

Daniel Rhodes's section (continued on opposite page) of the 218-foot Iowa history mural at the 1938 Iowa State Fair. From Greater Iowa, July, 1939.

Missourian Thomas Hart Benton and Kansan John Steuart Curry are the best-known of these painters, but their "regionalist" school of painting attracted many adherents, including Rhodes and Johnson. Regionalism appealed to many Americans during the depression, suggesting that the nation's hardy farm families and bountiful lands would persevere through hard times, rebuild the nation's prosperity, and keep alive its political virtue. Regionalist paintings seemed the visual embodiment of Americans' longstanding faith in the virtues of rural life. ${ }^{39}$

Commissioned by the federal government's Works Progress Administration to commemorate the centenary of Iowa's accession as a federal territory, Rhodes and Johnson's mural appears innocuous enough to a twenty-first-century observer. It depicts, on a grand scale, a conventional, triumphal tale of westward expansion, in which white Americans settled the frontier and transformed wilderness into civilization-precisely the enterprise that the fair had promoted and extolled for decades. The mural commences with a depiction of pioneers driving off In-

39. On regionalism, see Matthew Baigell, The American Scene: American Painting of the 1930s (New York, 1974); James Dennis, Grant Wood: A Study in American Art and Culture (New York, 1975); and Wanda Corn, Grant Wood: The Regionalist Vision (New Haven, CT, 1983), 25-33. Other accounts of Wood's career include Hazel E. Brown, Grant Wood and Marvin Cone: Artists of an Era (Ames, 1972); Joseph S. Czestochowski, John Steuart Curry and Grant Wood: A Portrait of Rural America (Columbia, MO, 1981); Darrell Garwood, Artist in Iowa: A Life of Grant Wood (1944; reprint, Westport, CT, 1971); Joan Liffring-Zug, ed., This is Grant Wood Country (Davenport, 1977); Barbara Melosh, Engendering Culture: Manhood and Womanhood in the New Deal Public Art and Theater (Washington, DC, 1991); Karal-Ann Marling, Wall-to Wall America: Post Office Murals in the Great Depression (Minneapolis, 1982); M. Sue Kendall, Rethinking Regionalism: John Steuart Curry and the Kansas Mural Controversy (Washington, DC, 1986); Belisario Contreras, Tradition and Innovation in New Deal Art (Lewisburg, PA, 1983. 


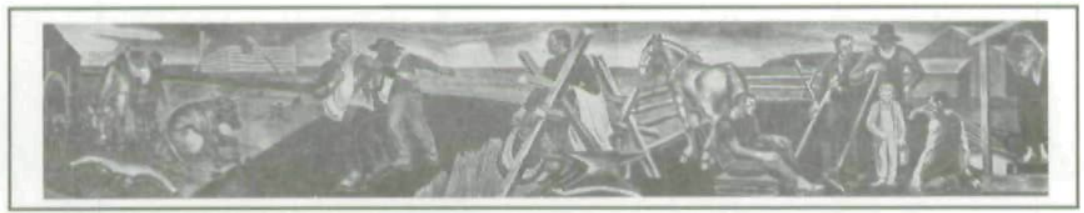

dians, surveying their newly conquered lands, plowing their fields, and building their homes, farms, towns, and factories. Near the center, however, a farmer sows grain with his left hand, a simple gesture that nonetheless stirred a tempest in the agitated political climate of the depression decade, leading many Iowans to complain to the fair board that Rhodes deliberately inserted this sinister figure prominently into the mural as a radical political symbol. If some Iowans disliked the left-handed farmer, even more detested what they interpreted as the mural's unflattering depiction of their state and their way of life. The controversy surrounding the left-handed farmer furnished a pretext for those who resented Rhodes's depiction of Iowans as hard-bitten and down-trodden. According to Wallaces' Farmer, "Farm people studied the pictures diffidently. It seemed queer to see farmers made the heroes of enormous drawings, to see farm men and women-some of them pretty hard-looking, too done on a scale and with colors hitherto reserved for ladies swathed in cheesecloth, representing the Spirit of Liberty." Fair officials demanded that the WPA order Rhodes to "correct" the picture, but the Iowa division of the WPA's Federal Art Project refused to infringe on Rhodes's artistic freedom by ordering him to alter his work. ${ }^{40}$

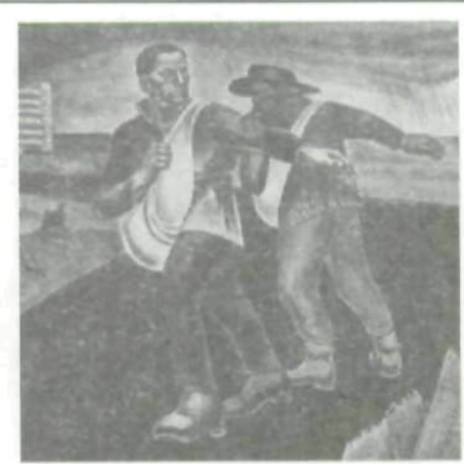

Detail of the left-handed sower from the above mural.

40. Wallaces' Farmer 63 (1938), 592; Iowa, WPA, Professional and Service Division, Scrapbook, vol. 2, Special Collections, Parks Library, Iowa State University; DMR, 8/24/1938. Rhodes and Johnson each painted half of the mural, with Rhodes executing the earlier years of Iowa history and Johnson the more recent decades. For details concerning the commission, see Francis Robert White to D. S. Defenbacher, Archives of American Art, WPA, Record Group 69, micro- 
Unable to compel Rhodes to change the mural, the fair board made a small but telling alteration of its own: visitors at the 1939 fair discovered that the painting had been captioned with Daniel Webster's oft-quoted aphorism (which had been invoked frequently at the fair since George Dixon's inaugural address in 1854, and might justifiably be regarded as the fair's credo): "When tillage begins, other arts follow. The farmers therefore are the founders of civilization." The addition of Webster's remark sought to frame Rhodes's depiction of Iowa history as a paean to the state's material progress and to the farmers who were the foundation of that progress; it also sought to deflect attention from the depiction of the rigors of farm life. Another artist, incensed by this minor yet significant alteration of the mural, responded angrily, "In the first place, the quotation isn't true. Cavemen drawings, representing a highly developed type of art, have been found in Spain. All evidence indicates these primitive people didn't know anything about soil tillage, and yet they were talented artists." The contention that artists, not farmers, were the true founders of civilization was tantamount to heresy, a refutation of the agrarian creed and mission of state and county fairs. ${ }^{4}$

World War II disrupted the state fair from 1942 to 1945, leading the fair board to suspend the exhibition and to allow the fairground to be used as a supply depot for the U.S. Army. The fair's reopening in 1946 after a four-year hiatus coincided with the centennial of Iowa's statehood and thus inspired yet another fair dedicated to history and progress. The fair's main gate, a gleaming, modern Art Deco structure, rose from stockade pickets, heralding a century of progress from the slow plodding of horse-drawn wagons to the marvel of commercial airplane travel. Inside the grounds, the fair boasted "100 Years of Iowa History on Parade" and promised to "turn back the calendar to the Glory and Glamour of frontier Iowa." The fair's historical exhibits in-

film reel DC 76, frames 1046-47; Francis Robert White to Thomas G. Parker, 8/17/1938, ibid., frames 1159-60; "Index Publicity" (5/3/1939), Iowa WPA Professional and Service Division Scrapbook, vol. 2 [n.p.], Special Collections, Parks Library, Iowa State University, Ames. On the response of ordinary Americans to regionalist painting, see Marling, Wall-to-Wall America; and Kendall, Rethinking Regionalism. Marling (48) notes the virtual obsession with uncovering the slightest hint of leftist political symbolism in New Deal murals. 41. DMR, 8/24/1939; ISAS, Report, 1854, 28. 


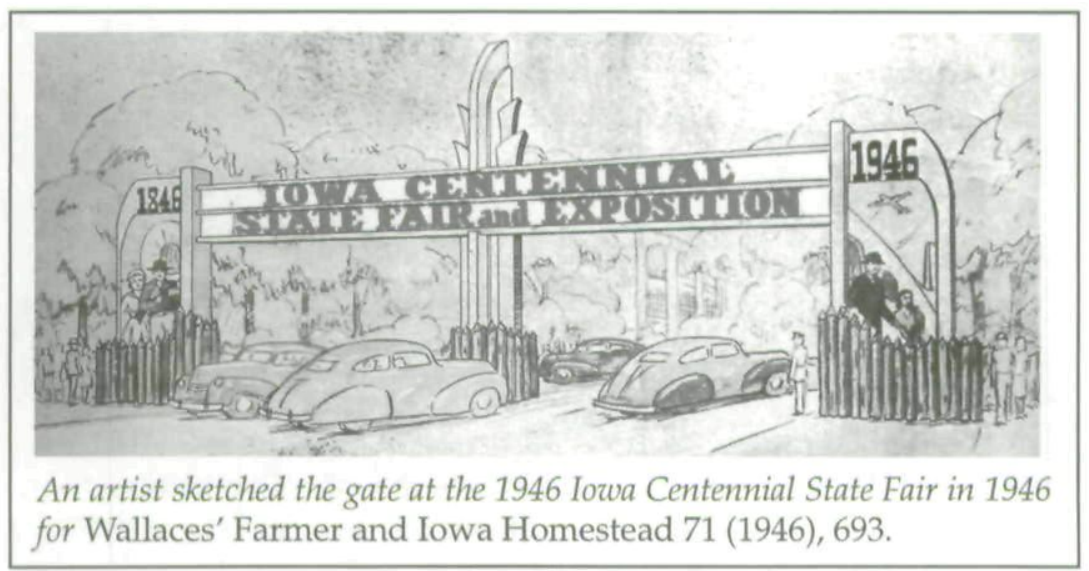

cluded displays of old machinery, modes of travel ranging from ox-carts to airplanes, a full-scale frontier farmstead, pictures of "Livestock Then and Now," and displays of the history of women's fashions and handicrafts. ${ }^{42}$

Ironically, the state fair's commemoration of Iowa's centennial also marked the loss of the panorama of Iowa history painted only eight years earlier by artists Dan Rhodes and Howard Johnson. Fair board secretary Art Cunningham ordered the mural removed from the Agriculture Building and its wood panels cut into scrap lumber to build shelves for the fair's exhibits. When asked about his decision to destroy a large, publicly funded work of art, Cunningham retorted, "The mural isn't art, it's WPA. It is an insult to Iowa farmers because it depicted them as club-footed, coconut-headed, barrel-necked and low-browed. ... It was a joke to have that thing on a fairground that's devoted to glorifying the Iowa farmer and his accomplishments." Cunningham added that he hoped that the fair board's destruction of the "monstrosity" would inspire Iowans to destroy other "so-called art-pieces which were foisted on them" by WPA artists in libraries, post offices, and other public buildings. For Cunningham, only unalloyed boosterism ought to be permitted at the fair, and Iowa's history must be depicted not as the result of hard work and struggle, but without even the slightest blemish. ${ }^{43}$

42. Wallaces' Farmer and Iowa Homestead 71 (1946), 715.

43. DMR, 6/25/1946. 
IN 1913 W. W. Dunkle, a writer for Billboard, the nation's leading show business magazine, whimsically envisioned "The State Fair of the Year 2000." By the outset of the third millennium, he predicted, technological progress and prosperity would completely transform the fair. Farmers would have long since relegated their Model T's to the scrap heap, whizzing to the fair in "private aerocars." At the sparkling, glass-enclosed fairground of the future, the livestock pens would no longer be covered with straw, and cattle would be displayed in gleaming, rotating glass pens. Meanwhile, on the midway, some five hundred acts would perform simultaneously atop an enormous, moving panorama."

At the outset of the twenty-first century, farmers are still earthbound, driving pickups on gravel and blacktop, 4- $\mathrm{H}$ members still exhibit livestock in a straw-covered show ring, and midways offer rides and games that would be recognizable to Americans of a century ago. During its early decades, the fair's watchwords were progress and improvement. But the basic elements of the fair-agricultural contests, commercial displays, games and shows-have remained substantially unchanged. For all its former devotion to progress, the fair is now firmly rooted in Iowa's past and links Iowans across the generations. Far from an incubator of innovation, the fair has assumed the mantle of a cherished annual ritual, which changes scarcely at all from year to year. Passing through the fair's gates, one enters a space reassuringly impervious to change- hence the Iowa State Fair's apt slogan, which proclaims proudly but nostalgically that it is "Still the One."

Today's fairgoers are pleased to discover that the fair does not change substantially or chase novelty from year to year, but reminds them of fairs past. The reassuring continuity between the fair and its predecessors, which has persisted in the face of tremendous economic, social, and cultural changes, suggests that the fair is no longer burdened with the responsibility of embodying and promoting the progress of the state, but has become a nostalgic reminder of a supposedly simpler time, when a vacation from the isolation and hard work of farm life, a stick of cotton candy, and a stroll across the fairground were ample 
diversion. As anthropologist Leslie Prosterman has observed, state fairs embody the values and aesthetics of their patrons and reinforce, rather than challenge, local standards of behavior and success. Formerly a brief respite from the rigors of farm life, the fair has now become, for many visitors, an opportunity to show their children what livestock actually look like on the hoof before they wind up wrapped neatly in plastic and displayed in the meat counter at the supermarket. The midway still bustles by day and glows by night, but the proliferation of theme parks and other diversions have made the fair's entertainments less unique, although no less attractive. ${ }^{45}$

Fairs remain, as cultural historian Karal Ann Marling writes, "our central cultural institution" in the Midwest, the very heart of states and counties throughout the region. ${ }^{46}$ Still, few midwesterners today would contend that the annual state or county fair embodies the sum total of the region's progress or leads the way toward its future development. Over its long history, however, the Iowa State Fair has recorded a good deal of Iowa's history by encompassing the enormous economic and cultural transformations that remade the state, as well as Iowans' responses to a century-and-a-half of momentous change.

In 1954, the Iowa State Fair marked its centennial with a series of historical exhibits and by erecting the Centurlon Spire of Time near the fair's Administration Building. Beneath this spire fair officials buried a time capsule of artifacts-seeds, letters from prominent Iowans, yearbooks, motion picture film-to be unearthed at the bicentennial state fair in 2054. The fair's twohundredth anniversary will surely inspire a new round of assessments of its history. Iowans fifty years hence will doubtless shake their heads at our primitive technology and outmoded ways as they struggle to locate a movie projector and thread the celluloid onto its sprockets. When the film flickers on the screen, though, they will doubtless recognize much of the 1954 state fair as their own.

45. Leslie Mina Prosterman, Ordinary Life, Festival Days: Aesthetics in the Midwestern County Fair (Washington, DC, 1995).

46. Karal Ann Marling, Blue Ribbon: A Social and Pictorial History of the Minnesota State Fair (St. Paul, MN, 1990), vii. 
Copyright of Annals of Iowa is the property of State of Iowa, by \& through the State Historical Society of Iowa and its content may not be copied or emailed to multiple sites or posted to a listserv without the copyright holder's express written permission. However, users may print, download, or email articles for individual use. 